\title{
Uma filosofia do cogito ferido: Paul Ricoeur ${ }^{(1)}$
}

\author{
JEANNE MARIE GAGNEBIN
}

\begin{abstract}
A TRADUÇÃO DE várias obras recentes de Paul Ricoeur nos últimos anos oferece uma ocasião privilegiada de apresentar ao público brasileiro a trajetória, simultaneamente excêntrica e exemplar, desse filósofo contemporâneo. Trajetória excêntrica com relação ao suposto centro que figuraria o Hexagone, a França e, em particular, Paris. Ricoeur é um dos poucos filósofos franceses atuais que não só lê e traduz do alemão e do inglês, mas também dialoga com correntes internacionais de pensamento tão diversas como a fenomenologia alemã (traduziu as Idéias I de Husserl já em 1950), a hermenêutica de Gadamer ou a filosofia analítica inglesa e norte-americana. Esse diálogo múltiplo, aliás, constitui considerável parte de seus textos. Em Tempo e narrativa, por exemplo, a discussão com Agostinho e Aristóteles, com Husserl e Heidegger, mas também com Braudel, Danto, White, Propp, Greimas, Weinrich, sem falar em Thomas Mann e Proust, ocupa mais da metade da obra. Tal confrontação com pensamentos alheios levou à crítica muito freqüente de que Ricoeur não teria um pensamento próprio. Só saberia, como um bom professor (meio chato como são os bons professores!), expor as idéias dos outros e corrigir-lhes os excessos. Gostaria, aqui, não apenas de defender uma originalidade estonteante da filosofia de Ricoeur - tal originalidade, aliás, me parece pertencer a pouquíssimos, apesar das afirmações mercadológicas contrárias -, mas de ressaltar sua coerência e sua generosidade. A questão central da obra, pois, poderia ser tematizada como a tentativa de uma hermenêutica do si pelo desvio necessário dos signos da cultura, sejam eles as obras da tradição ou, justamente, as dos contemporâneos. A discussão aprofundada de outros pensadores aponta não só para um hábito acadêmico e professoral, mas, muito mais, para uma abertura e uma generosidade no pensar que vai em direção oposta a certo narcisismo jubilatório e esotérico característico de muitas modas filosóficas (e outras) contemporâneas.
\end{abstract}

Trajetória exemplar, portanto, se considerarmos como seu início a recepção da fenomenologia husserliana nos anos 50 e seu último livro mais sistemático, Soimême comme un autre (2), que já traz inscrita no seu belo título a questão da identidade (Soi-même) e de uma invenção da identidade através das figuras da alteridade: comme un autre, insistindo tanto na dimensão metafórica como também ética dessa invenção. Ora, essa questão já se encontrava, segundo Ricoeur, no centro de seu interesse pela fenomenologia husserliana. Com efeito, seu impacto sobre o jovem filósofo não provém de sua pretensão a uma fundamentação originária e imediata da fenomenalidade pela consciência pura - pretensão certamente presente e importante - mas de sua insistência na intencionalidade dessa mesma 
consciência, isto é, da relação essencial e primeira da consciência ao mundo fora da consciência. Em outras palavras, a fenomenologia husserliana rompe "a identificação cartesiana entre consciência e consciência de si" ou ainda permite "escapar ao solipsismo de Descartes (...) para levar a sério o quadro histórico da cultura" (Rf) (3).

Desde o início, portanto, Ricoeur se situa num certo combate às versões mais exacerbadas do idealismo, em particular à pretensão de auto-suficiência da consciência de si, para ressaltar os limites dessa tentativa. Limites entendidos, seguindo a empresa crítica de Kant, como as demarcações intransponíveis da racionalidade e da linguagem humanas, sob pena de cair nas aporias ou, pior, na hybris (des-medida) de um pensamento que se auto-institui em absoluto; mas limites também no sentido de uma fronteira que aponta, por sua própria existência, para um outro país, para uma outra região que o território da consciência auto-reflexiva. Essa problemática das fronteiras e das regiões (ver os subtítulos dos volumes 2 e 3 das Leituras) é, portanto, dupla na reflexão de Ricoeur: crítica, certamente, mas também e inseparavelmente aberta, cheia de curiosidade. Ao reconhecer seus limites, a consciência filosófica não se restringe à sua auto-reflexão solipsista, mas reconhece, com um certo alívio alegre, que existe algo fora dela, e mais, que esse algo é tão fundamental como apaixonante. A luta contra os exageros da tradição idealista, que Ricoeur aponta como o motivo primeiro de sua filosofia, desemboca assim numa pesquisa apaixonada das relações dessa consciência - e desse sujeito - com o mundo que os circunscreve e os constitui por inúmeros laços. Em termos heideggerianos que Ricoeur gosta de usar: a pesquisa das inúmeras maneiras do sujeito humano habitar o mundo e torná-lo mais habitável. À "exaltação do Cogito" se opõe um Cogito "quebrado" (brisé) ou "ferido" (blessé) como o escreve Ricoeur no prefácio a Si mesmo como um outro. Mas essa quebra é, simultaneamente, a apreensão de uma unidade muito maior, mesmo que nunca totalizável pelo sujeito: a unidade que se estabelece, em cada ação, em cada obra, entre o sujeito e o mundo.

É, nesse contexto, digno de menção que os primeiros livros de Ricoeur tratam de uma Filosofia da vontade (4) ou, melhor, daquilo que coloca radicalmente em questão a onipotência da vontade humana: a finitude, a culpabilidade, o mal, justamente figuras dolorosas do involuntário. Notemos também que o problema do mal é abordado desde já pelo viés de sua simbólica, de seus símbolos primários e de seus mitos. Delineia-se assim, como Ricoeur mesmo o assinala, uma questão essencial: o mal, fonte de sua reflexão ética e política; e um caminho de acesso privilegiado: os símbolos, os mitos, isto é as invenções lingüísticas e narrativas que os homens elaboram para tentar converter em sentido(s) o real que encontram e que os submerge. Já nessa obra inicial, portanto, alguns temas- chave da reflexão de Ricoeur eram postos: a não-soberania do sujeito consciente e sua relação simbólica e cultural com esse outro que lhe escapa.

Enquanto esse primeiro livro ainda era bastante tributário da fenomenologia da religião - em particular de Mircea Eliade -, o confronto com as ciências humanas e a filosofia dos anos 60 e 70, na França, permite a Ricoeur afinar melhor dois 
conceitos centrais: os de sujeito e de interpretação. A discussão filosófica dessas décadas é, pois, marcada por várias tentativas de destronar não só a filosofia clássica do sujeito autônomo (Descartes e Kant), mas também seus sucedâneos contemporâneos, o existencialismo e o personalismo, com sua ênfase nos conceitos de responsabilidade e de decisão. Olhando retrospectivamente para essa época, Ricoeur distingue três correntes distintas, mas que se reforçam mutuamente nessa denúncia do humanismo metafísico, tal como Heidegger, nas pegadas de Nietzsche, o tinha definido: primeiro, um pensamento poetizante que se reclama, justamente, do segundo Heidegger; depois, o estruturalismo tanto lingüístico como, sobretudo, antropológico (Lévi-Strauss); enfim, a renovação da psicanálise com a doutrina lacaniana. Os três movimentos têm em comum a convicção de que não há sujeito algum que seja mestre de sua fala, como se possuísse liberdade e soberania sobre ela, mas que o discurso do sujeito representa muito mais o veículo através do qual algo, muito maior que ele, se diz: a dinâmica de encobrimento e de descoberta do Ser, o sistema de relações que estruturam o corpo social, o inconsciente. Mesmo que não neguem as variações pessoais e estilísticas, essas tendências teóricas tendem a transferir a dinâmica de liberdade e de invenção, tradicionalmente atribuída à pessoa do sujeito individual, para uma entidade sistêmica tão eficaz como impessoal.

Esse debate, ao qual a versão althusseriana do marxismo deverá também contribuir, encontra em Ricoeur um observador atento, mas distanciado. Como já vimos, Ricoeur andava desde sempre desconfiado com relação à afirmação idealista clássica da soberania do sujeito. Não sente, portanto, como alguns de seus colegas, a necessidade de sair apressadamente em defesa dessa figura contestada. Mas tampouco aceita um certo entusiasmo desvairado pelos novos modelos teóricos, que deviam engendrar muitos fanáticos. Sua resistência não diz respeito às aquisições descritivas que tais metodologias oferecem; ao contrário, as análises estruturalistas, sobretudo de textos, serão amplamente discutidas e aproveitadas por Ricoeur. Sua desconfiança surge no que concerne à pretensão de totalização que alguns usos desenfreados do estruturalismo e de outros ismos sugerem: como se esses modelos pudessem não só descrever e analisar as produções culturais e lingüísticas, mas também explicar suas formas históricas de surgimento e de invenção. Aqui, novamente, Ricoeur desconfia da mesma tendência a uma bybris totalizante que já denunciava no solipsismo cartesiano e que ele fareja na aplicação acrítica - isto é, que não reconhece seus limites - dos recentes paradigmas anticartesianos.

Frutos dessas controvérsias são os dois livros: Da interpretação. Ensaio sobre Freud, de 1965; O conflito das interpretações. Ensaios de hermenêutica, de 1969. Como o leitor pode logo perceber, o destaque recai numa discussão muito elaborada do próprio conceito de interpretação. Ricoeur observa que seus primeiros escritos repousavam sobre uma noção amplificante de interpretação: uma "interpretação atenta ao acréscimo de sentido incluído no símbolo e que a reflexão tinha por tarefa liberar" (Rf); o confronto com Freud, Marx e Nietzsche - através do confronto com a psicanálise, com o estruturalismo, entre outros marxista, e com o pós-heideggerianismo -, "esses três grandes mestres da suspeita", leva-o a 
admitir outra possibilidade de interpretação: uma interpretação redutora, isto é, de denúncia das ilusões, genealógica no sentido de Nietzsche, de crítica ideológica em Marx, de descoberta do recalque e da repressão em Freud. Dessas leituras, portanto, Ricoeur tira ainda mais munição para a sua empresa de desmistificação das pretensões teóricas totalizantes. Ele ganha, igualmente, instrumentos privilegiados de análise da relação temporal que subjaz à prática hermenêutica. Como as manifestações culturais, individuais ou coletivas não se constituem a partir de uma produção linear e tranqüila de sentidos acumulados, mas surgem também de conflitos, de deslocamentos, de disfarces e de transferências, assim também a relação entre o presente do intérprete e o passado (mais ou menos longínquo) da obra interpretada não se resume à mera relação de aceitação e de transmissão. A própria transmissão da tradição obedece a motivos e interesses diversos, explícitos ou implícitos, tematizados ou inconscientes, que interferem no processo hermenêutico enquanto tal. No processo interpretativo confrontam-se sempre dois mundos, o da obra e o do intérprete. Ambos devem ser refletidos. A dinâmica da compreensão comporta, porém, certo apagamento do intérprete em favor da obra; uma "desapropriação de si" para deixar o texto, por exemplo, nos interpelar na sua estranheza e não só nos tranqüilizar naquilo que nele projetamos, mas também produzir, graças ao confronto entre o universo do intérprete e o universo interpretado, uma transformação de ambos. Em certo sentido, Ricoeur é mais radical que Gadamer quando esse falava de uma reapropriação (Aneignung) da obra pelo intérprete. $\mathrm{O}$ processo hermenêutico, poderíamos dizer, desapropria duplamente o sujeito da interpretação: obriga-o a uma ascese primeira diante da alteridade da obra; e, num segundo momento, desaloja-o de sua identidade primeira para abri-lo a novas possibilidades de habitar o mundo. Em Tempo e narrativa, Ricoeur dará a essa transformação da experiência do intérprete (e do leitor) o nome de refiguração.

Mas fiquemos ainda nessas discussões dos anos 70: a ênfase dada aos processos de transformação não só da visão do objeto, mas também da maneira de ver do sujeito da interpretação, leva Ricoeur a trabalhar em detalhe a lingüística da enunciação de Emile Benveniste. Contra um estruturalismo estreito que defenderia a extinção da noção de sujeito, a semântica de Benveniste, em particular sua definição do discurso como um enunciado estruturado pela relação entre aquele que toma a palavra e aquele a quem se endereça essa palavra, permite uma reelaboração da noção de sujeito sem cair nas rédeas do individualismo costumeiro. Munido desses instrumentos lingüísticos mais finos, Ricoeur se propõe, então, à retomada da problemática do sujeito e de sua relação a outrem e ao mundo, através de um estudo muito mais preciso e circunscrito: a análise do "fenômeno da inovação semântica, ou, dito de outra maneira, da produção de um sentido novo através de procedimentos lingüísticos (procédures langagières)" (Rf). Tal proposta, lembremos, já se encontrava em germe nas interpretações da Symbolique du mal. Com certo receio em relação às vagas noções de símbolo e de mito que ele mesmo usou, Ricoeur enfrenta agora a problemática da criação do sentido em duas etapas distintas: primeiro, nesse livro cerrado, de 1975, que é La métaphore vive; e, mais tarde, nos três imponentes volumes de Temps et récit (respectivamente de 1983, 1984, e 1985). 
Não é o lugar, aqui, de tecer comentários detalhados sobre esse livro difícil, às vezes de leitura ingrata, que é a Métaphore vive. Dificuldade tributária das discussões técnicas muito agudas com diversas correntes da filosofia analítica e da lingüística, exercício de rigor que visa a corrigir a amplitude do conceito de símbolo ( mis à toutes les sauces, como o diz Ricoeur). Podemos, porém, observar que na tradição filosófica clássica, a metáfora constitui um problema crucial para qualquer definição da linguagem que tente estabelecer uma partilha definitiva entre o sentido literal e o sentido figurado, isto é, também entre o real (ou o verdadeiro) e o fictício (ou o falso). Essas resistências, que Derrida deverá analisar com brilho no seu famoso artigo sobre $A$ metáfora no texto filosófico (5), remetem a uma definição da verdade da linguagem em termos predominantes de adequação e de referência unívoca. Nesse contexto, a metáfora sempre é vista como um desvio perigoso porque ameaça a transparência (ideal, pois nunca alcançada) da linguagem com relação ao mundo. Em reação a essa condenação tradicional da metáfora, certas teorias filosóficas e literárias contemporâneas pecam pelo excesso oposto: optam pela não-referencialidade de princípio da literatura (à diferença da linguagem comum), pela opacidade esplêndida do discurso literário que só remeteria a si mesmo, num jogo textual e intertextual simultaneamente infinito e encerrado "na clausura de sua própria textualidade" (CC). Como muitas vezes, Ricoeur adota uma posição mediana - tal postura lhe atrai tanto o ódio dos desconstrutivistas fanáticos, como o desdém complacente dos analíticos xiítas! Uma tomada de posição resumida, mas muito clara, pode ser lida no artigo de 1977 Entre filosofia e teologia II: nomear Deus, publicado agora no volume 3 das Leituras. Contra uma glorificação do sentido, isto é, de uma "rede de relações puramente internas ao texto" em oposição à sua dimensão referencial, Ricoeur afirma que a "escrita" - em particular a escritura literária - "não abole, mas (...) transforma" essa função referencial. Por sua vez, essa função não pode ser reduzida unicamente à adequação de uma linguagem descritiva a um objeto preciso, como o defendem alguns filósofos herdeiros de Frege. Ricoeur propõe a amplificação da noção de referência, de tal maneira que essa não signifique somente uma relação de manipulação dos "objetos" do discurso pelo seu "sujeito", mas também - e talvez mais originariamente - uma relação de pertencimento (appartenance) desse sujeito ao mundo. Vemos aqui, com nitidez, como a vertente fenomenológica do pensamento de Ricoeur o defende dos encantos entrecruzados do estruturalismo, da desconstrução e também da filosofia analítica. "Se nos tornamos cegos para essas modalidades de enraizamento e de pertencimento que precedem a relação de um sujeito com objetos é porque ratificamos de maneira não-crítica um certo conceito de verdade, definido pela adequação a um real de objetos e submetido ao critério da verificação e da falsificação empíricas. $O$ discurso poético questiona precisamente esses conceitos não criticados de adequação e de verificação. Ao fazer isso, ele questiona a redução da função referencial ao discurso descritivo e abre o campo de uma referência não-descritiva do mundo.”

Agora que situamos Ricoeur na paisagem movediça dos anos 70, na França, entendemos melhor l'enjeu essencial da Métaphore vive e de Temps et récit. Trata-se, ambas as vezes, através da análise da inovação semântica, de pesquisar as transformações que os homens podem instaurar na experiência complexa por meio da qual 
se situam no mundo. Em última instância, é o caráter fundamentalmente lingüístico (langagier/sprachlich) da experiência, tal como já Hegel e Freud o ressaltavam, que permite a compreensão de si e a compreensão das possibilidades de transformação de si e do mundo. O estudo dessas definições e inovações da identidade no plano poético e no plano narrativo são, igualmente, o reconhecimento prático da impossibilidade, para o sujeito, de se apreender imediatamente a si mesmo, a "ruína definitiva (...) do ideal cartesiano, fichteano e, em boa parte também, husserliano de uma transparência do sujeito a si mesmo" (Rf). A idéia de uma compreensão de si e do mundo passa necessariamente - eis uma nova definição da hermenêutica pela análise dos signos e das obras que encontramos no mundo e que precedem nossa existência individual.

Percebemos agora que a tarefa hermenêutica no sentido clássico da interpretação da tradição se desdobra numa tarefa mais ambiciosa: a da interpretação e da compreensão não apenas do(s) sentido(s) já dado(s), mas igualmente dos processos de criação de sentido(s). Paralelamente, cresce o interesse de Ricoeur pela temática ética e política, por uma teoria da ação, interesse que o contato com a filosofia analítica norte-americana deveria reforçar (desde 1970, Ricoeur dá cursos regulares na Universidade de Chicago). O empreendimento dos três volumes (6) de Tempo e narrativa testemunha, igualmente, essa passagem Do texto à ação, título de uma segunda coletânea de ensaios hermenêuticos publicada em 1986. Tal afirmação pode parecer paradoxal: não teríamos aqui análises predominantemente discursivas, seja de textos de ficção, seja de textos históricos? Sem dúvida. Mas o título comporta uma outra - e primeira - palavra: Tempo, essa dimensão tão inescrutável como essencial do agir humano. Desde sempre, nos confessa o filósofo, a temática do tempo o perseguia; mas só conseguiu aproximar-se dela através da retomada da belíssima interrogação de Santo Agostinho, no Livro XI das Confissões. Mais precisamente, apenas quando Ricoeur, por assim dizer, redescobre, nas pegadas de Agostinho, a ligação íntima entre tempo humano e narração (7); ou, ainda, aludindo à famosa definição lacaniana do inconsciente, "que o tempo é estruturado como uma narrativa/narração" (CC) (8), somente nesse momento pode se desdobrar o edifício comparativo entre as estratégias narrativas da história e da ficção. O outro elemento teórico decisivo dessa construção provém da Poética de Aristóteles, da sua teoria do mythos e do enredo (9) narrativo como mimesis praxeôs, representação da ação. Entre a questão aporética sobre a essência do tempo - nas famosas palavras de Agostinho: "Que é, pois, o tempo? Quem poderá explicá-lo clara e brevemente? Quem o poderá apreender, mesmo só com o pensamento, para depois nos traduzir com palavras seu conceito? (...) O que é, por conseguinte, o tempo? Se ninguém mo perguntar, eu sei, se o quiser explicar a quem me fizer a pergunta, já não sei." (Confissões, XI:14-17) - e a interrogação ansiosa sobre as condições e as possibilidades da ação justa, intervêm, portanto, os elos de uma reflexão sobre o caráter narrativo da experiência temporal e sobre a disposição ou ordenação narrativa (mythos) dos diversos momentos da ação. Somente esses elos narrativos intermediários permitem pensar, no sentido forte da palavra, a temporalidade e a prática humanas, sem cair nos abismos vizinhos do ceticismo e do imediatismo. 
Para entender melhor as diferenças e as semelhanças entre narrativa ficcional e narrativa histórica, Ricoeur lança mão de dois conceitos complementares: a configuração, isto é, "as operações narrativas elaboradas no interior mesmo da linguagem" e do texto, por exemplo, as formas do enredo e a construção das personagens; e a refiguração, ou seja, "a transformação da experiência viva sob o efeito da narração" (CC). O primeiro volume estuda mais especificamente a configuração das narrativas históricas, em particular no debate que opõe os partidários do eclipse do acontecimento na historiografia francesa contemporânea aos argumentos da filosofia analítica de língua inglesa (Dray, von Wright e Danto), que insistem na dimensão narrativa, mas não-necessariamente explicativa no sentido forte do termo, da historiografia. O segundo volume apoia-se em várias pesquisas estruturalistas (Propp, Greimas) e nos trabalhos consagrados às relações entre tempos verbais e tempo (Tempus e Zeit) ou, ainda, entre tempo da narração e tempo narrado, em particular na tradição alemã (Weinrich, Müller), para desembocar em esplêndidas análises

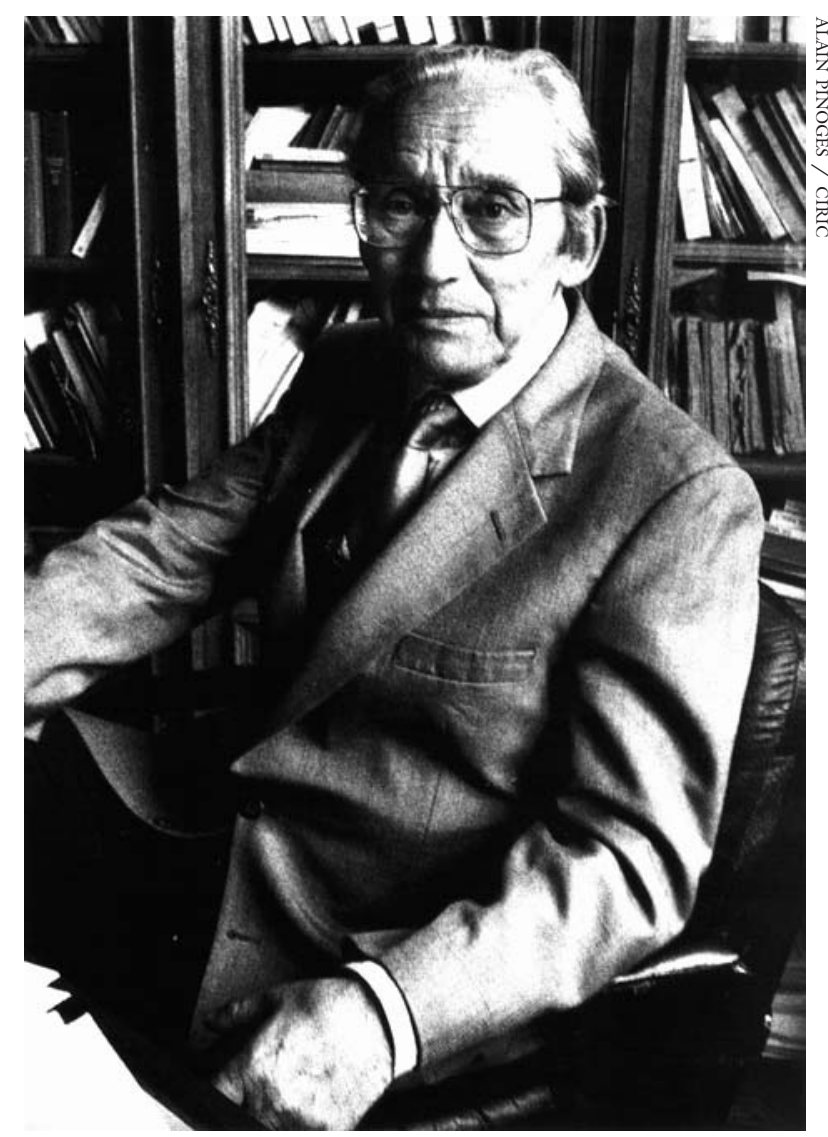

O filósofo francês Paul Ricoeur

da "experiência temporal fictícia" de três romances modernos sobre o tempo e do tempo: Mrs. Dalloway, de Virginia Woolf; A montanha mágica, de Thomas Mann; por fim, Em busca do tempo perdido, de Proust. Não é o caso aqui de entrar nos detalhes desse trabalho gigantesco. Só queria ressaltar o sentimento muito forte que se apodera do leitor enredado (!) pela estratégia argumentativa e narrativa de Ricoeur: a saber, o sentimento que somente a arte da narração nos poderia reconciliar, mesmo que nunca definitivamente, com as feridas e as aporias de nossa temporalidade, marca inequívoca de nossa finitude e de nossa morte e, simultaneamente, de nossa incapacidade em dar de nós mesmos outras imagens e outros conceitos que as formas efêmeras da história. O tempo nos escapa e, por ele, como que escapamos de nós mesmos; mas a retomada dessa fuga na matéria frágil das palavras (10) permite uma apreensão nova, diferente da queixa costumeira sobre a vaidade do tempo e da vida, dessa nossa experiência da fugacidade. Uma nova apreensão que ao criar sentidos, fugazes eles também, permite jogos ativos com o(s) tempo(s) e no(s) tempo(s), isto é, uma inter-ação com ele(s) (o plural quer assinalar um dos efeitos dessa interação: a descoberta de várias espessuras do tempo, de ritmos diferenciados, de tempos distintos ou entremes-clados). 
É justamente nesse momento de refiguração, de remanejamento da experiência temporal, graças ao texto, que se situam, segundo Ricoeur, as maiores diferenças entre narrativa histórica e narrativa ficcional. A história remodela a experiência do leitor por "uma reconstrução do passado baseada nos rastros por ele deixados" (Rf), a partir de uma ausência portanto, enquanto a ficção transforma a experiência temporal a partir de sua irrealidade preciosa. Se ambas podem usar estratégias narrativas semelhantes, mecanismos de configuração parecidos ou mesmo idênticos, o momento de refiguração do mundo do leitor difere, em particular de sua experiência temporal. A essas diferenças e semelhanças, a seus cruzamentos, é consagrado o terceiro volume de Temps et récit (11) que culmina com uma nova interrogação sobre o sujeito, mais especificamente sobre a identidade narrativa. "O que chamamos de identidade narrativa, tanto dos indivíduos como das comunidades históricas", pergunta Ricoeur, "não seria o produto instável do entrecruzamento entre história e ficção?” (Rf). O próximo livro, Si mesmo como um outro, deverá retomar tal discussão.

Duas observações se impõem no fim desse rápido percurso consagrado a Tempo e narrativa. A primeira: mesmo que o tempo se torne tempo humano e psíquico pela sua estruturação narrativa, o enigma do tempo cronológico e da relação entre tempo humano e tempo cronológico permanece. Em outros termos, Ricoeur resguarda a inescrutabilidade (Unerläutbarkeit) última do tempo, à qual Kant já aludira. Manter, pois, a totalidade do tempo "presa nas redes do narrativo" seria devolver ao sujeito esses poderes absolutos que lhe emprestava o idealismo, como se ele "fosse senhor do sentido, como se ele mantivesse encerradas na narrativa todas significações das quais o tempo é suscetível" (CC). Poderíamos dizer que, para Ricoeur, não só o tempo escapa à empresa de totalização do sujeito, mas também, paradoxalmente, que a liberdade subjetiva de invenção, isto é, também de jogo com o imprevisivel e o imprevisto, nasce dessa nãomanipulabilidade última (um dos últimos capítulos de Temps et récit III traz o eloqüente título: Renunciar a Hegel!).

Segunda observação no nosso percurso: o conceito de refiguração, de transformação da experiência temporal do leitor, apela para um conceito enfático de leitura como atividade específica de recepção e de reapropriação transformadora. Nesse conceito, convergem as reflexões oriundas tanto da estética da recepção de Jauss quanto da hermenêutica de Gadamer. Mas ele já tinha sido esboçado nas últimas páginas da Busca do tempo perdido que Ricoeur gosta de citar: "Mas, para voltar a mim, pensava mais modestamente em meu livro, e seria mesmo inexato dizer, pensando naqueles que o leriam, em meus leitores. Pois não seriam, segundo mim, meus leitores, mas os próprios leitores de si mesmos, meu livro não passando de uma espécie de lentes de aumento como aquelas que oferecia a um freguês o dono da ótica de Combray; meu livro graças ao qual eu lhes forneceria o meio de lerem a si mesmos." (12).

Esse conceito forte de leitura ressurge no título dos três volumes lançados pela Editora Loyola, na tradução cuidadosa de Perine e Campanário; eles oferecem uma coletânea preciosa de artigos dispersos em diferentes revistas de acesso 
nem sempre fácil. A escolha, efetuada pelo próprio Ricoeur, é testemunha justamente de uma certa leitura que o filósofo faz de si mesmo, de sua trajetória intelectual através da leitura de outros autores, filósofos ou não. Mas a tripartição das Leituras - Em torno ao político; A região dos filósofos; Nas fronteiras da filosofiatambém remete a outra questão, a do lugar contemporâneo da filosofia. Uma pequena análise desses três subtítulos já revela o cuidado de Ricoeur em delimitar tal território. Assim, por exemplo, a questão do político é tão essencial ao pensamento filosófico como, também essencialmente, o extrapola. Não só porque a prática dos homens sempre escapa de sua previsão e ultrapassa sua auto-reflexão - nesse sentido, a faz avançar, mesmo a contragosto -, mas porque a questão do político para Ricoeur se enraíza nesse insondável do pensar que representa o problema do Mal. Seu grande interesse por Hannah Arendt ou por Jaspers - ambos pensadores da experiência da Segunda Guerra, em particular da realidade do nazismo e do horror inominável da Shoah, sua retomada da problemática do Mal radical (Kant) -, atestam essa motivação primeira. Assim também a preocupação com os conceitos de violência (artigos sobre Eric Weil) e de resistência (a propósito de Jan Patocka). "O mal, como o tempo, é aporético no sentido que ele suscita impasses que o pensamento tem por dever meditar" (13). Como o tempo, mas de maneira muito mais dramática, a explicação do mal escapa ao pensamento, apesar de todas as tentativas e tentações de teodicéia que os homens, em particular os filósofos, se comprazem em construir. Fiel a essa denúncia de qualquer justificativa daquilo que permanece injustificável, a reflexão política de Ricoeur evita propostas totalizantes e desemboca numa reflexão ética sobre o justo (artigos sobre Rawls), cujo estatuto epistemológico remete, seguindo sem dúvida o ensinamento aristotélico, muito mais à sabedoria prática que ao saber ou à ciência. Essa junção de humildade epistemológica e de responsabilidade ativa caracteriza a filosofia política de Ricoeur e a inscreve na linhagem da filosofia prática de Kant.

Os artigos do segundo volume têm um interesse histórico em duplo sentido: documentam o itinerário e a evolução do próprio Ricoeur, como também os debates dos anos 50 e $60 \mathrm{com}$ as diversas correntes dos pensadores da existência. Chama também atenção, aqui, a ênfase dada por esses últimos e por Ricoeur à questão do mal, que, aliás, deverá voltar no terceiro volume. A segunda parte desse segundo volume oferece uma amostra do confronto de Ricoeur com questões estéticas e narrativas em artigos que preparam as obras maiores como a Métaphore vive e Temps et récit.

Gostaria de me demorar um pouco mais na problemática do terceiro volume das Leituras, Nas fronteiras da filosofia, porque é nele que encontramos o confronto com os domínios limítrofes da filosofia, em particular com os domínios da religião e da teologia. Ora, como o observa Olivier Mongin, cujas pequenas notas editoriais são sempre elucidativas, a pecha de filósofo cristão foi, e é, um dos motivos mais freqüentemente alegados para rejeitar - aliás geralmente sem estudá-la minimamente - a reflexão de Ricoeur. Rejeitado como criptoteólogo por alguns, reivindicado como pensador cristão por outros, Ricoeur teve de lutar em ambas as frentes: contra seus criticos, mostrar que sua filosofia não se reclama, na sua argumentação interna, de sua fé; contra seus admiradores, que seu pensamento filosó- 
fico não oferece fundamentação racional para crença alguma. Pelo contrário, afirma que sempre tratou de distinguir cuidadosamente entre seus trabalhos mais teológicos (sobretudo de exegese bíblica) e filosóficos, que ele sempre quis e quer "manter, até à última linha, [como] um discurso filosófico autônomo". Continua ele, no prefácio a Si mesmo como um outro, citado por Mongin na nota editorial do terceiro volume das Leituras: "Observar-se-á que esse ascetismo do argumento, que marca, creio eu, toda a minha obra filosófica, conduz a uma filosofia da qual a nominação efetiva de Deus está ausente e na qual a questão de Deus, enquanto questão filosófica, permanece em um suspense (melhor: 'em suspensão') que podemos chamar de agnóstico". Em outras palavras: a fé cristã (que Ricoeur nunca negou professar) não intervém como fundamento religioso-mágico, como Deus ex machina ou, numa vertente mais refinada, como o Deus dos filósofos. A reflexão de Ricoeur poderia ser chamada, segundo sua bela expressão sobre seu amigo Pierre Thévenaz, o filósofo suíço prematuramente morto, uma "filosofia sem absoluto". Nesse contexto, poderíamos afirmar dos leitores de Ricoeur, tanto daqueles que reivindicam seu cristianismo como daqueles que o rechaçam, que ambos se assemelham aos intérpretes bem intencionados de Kafka, que liam sua obra como uma alegoria religiosa disfarçada, em vez de compreender a interdição essencial que a estrutura. E poderíamos, a propósito de Ricoeur, parafrasear W. Benjamin a propósito de Kafka: "Já se observou que na obra inteira de Kafka o nome de Deus não aparece. E nada mais habitual que introduzi-lo na sua interpretação. Quem não entende o que proíbe a Kafka o uso desse nome não entende nenhuma linha dele" (14).

Seria, porém, simples demais afirmar que a reflexão filosófica de Ricoeur não tem nada a ver com sua fé religiosa. Tem sim, mas não no sentido habitual de uma resposta da fé às aporias da razão, mas muito mais - é a hipótese que gostaria de defender por fim -, justamente nessa separação estrita entre os domínios da fé e da razão, nessa ascese, oriunda de Kant (e da tradição protestante em Kant também!), da argumentação racional que, ao reconhecer seus limites, se dispõe também a reconhecer a possibilidade de um Outro que lhe escapa. Nesse contexto, a definição por Ricoeur do religioso como "a referência a uma antecedência, a uma exterioridade e a uma superioridade", sendo que essas "três noções são constitutivas da maneira como sou precedido no mundo do sentido" (CC), aponta não tanto para uma confissão determinada, mas, muito mais, para o reconhecimento do sagrado como aquilo que, simultaneamente, nos precede e nos ultrapassa. Ricoeur retoma várias vezes essa especificação, em particular quando se the perguntou sobre o papel do cristianismo para seu pensamento. Responde pela presença de uma economia do dom mais fundante que uma economia estritamente racional da troca ou do lucro, e por uma relação com o sagrado, intimamente ligada a essa economia da dádiva ou da graça, e cuja conseqüência essencial é destronar o sujeito desse lugar central outorgado pela tradição filosófica moderna desde Descartes. Na mesma resposta, não teme em lembrar a crítica de Heidegger ao humanismo e o questionamento das pretensões do sujeito em Foucault pois iriam, segundo ele, na mesma direção que "minha convicção, a saber que o sujeito não é o centro de tudo, que ele não é o senhor do sentido" (15). 
Resta saber se essa conviç̧ão aponta exclusivamente para a noção de sagrado, se ela não poderia também remeter a uma realidade mais secular, talvez até psicanalítica, de aceitação da própria finitude em oposição à comunidade maior dos vivos - e dos mortos. Resta saber também se essa receptividade em relação a um sentido, talvez obscuro, mas anterior à existência individual do sujeito, pode ainda competir com a jubilação irônica e gloriosa do relativismo pós-moderno que, aliás, recoloca paradoxalmente o sujeito no centro desse palco efêmero, pois somente o brilho do seu desempenho devastador é motivo de gozo. Agora, assumindo de vez um tom polêmico, eu diria que, nesses tempos de triunfalismo neoliberal e de narcisismo de príncipe e de princípio, um pensamento que chacoalha a gloríola do sujeito e lhe lembra, simultaneamente, sua inscrição na história e sua finitude, só pode ser bem-vindo; ele recorda à filosofia uma luta antiga, que não se tornou vã depois de Nietzsche e da morte de Deus: a luta contra os ídolos, em particular contra aqueles que o próprio pensamento tende a erigir para si mesmo em substituição dos deuses mortos.

Notas

1 Paul Ricoeur, Tempo e narrativa (t. I, 1994 e II, 1995), Papirus. Leituras (1, Em torno ao político, 1995; 2, A região dos filósofos, 1996; 3, Nas fronteiras da filosofia, 1996), Loyola.

2 A tradução brasileira O si mesmo como um outro, Papirus, 1990, deixa, infelizmente, bastante a desejar.

3 Esse artigo baseia-se em três livros essenciais para entender a trajetória intelectual de Ricoeur. Dois do próprio autor: um ensaio intitulado Réflexion faite. Autobiographie intellectuelle, Ed. Esprit, 1995, versão francesa do ensaio publicado em inglês no início do livro The philosophy of Paul Ricoeur, L.H. Hahn (ed.), Chicago and Lassale, Library of Living Philosophers, 1995); uma coletânea de entrevistas com F. Azouvi e M. de Launay, La critique et la conviction, Calmann-Lévy, 1995; enfim, um livro consagrado ao pensamento de Ricoeur, Paul Ricoeur, por Olivier Mongin, Seuil, 1994. Para não cansar o leitor, escreverei as citações entre aspas, mas somente indicarei entre parênteses (Rf) para Réflexion faite, (CC) para La critique et la conviction, ou, então, $(\mathrm{OM})$ para o livro de Olivier Mongin.

4 Philosophie de la volonté, v. 1, Le volontaire et l'involontaire; v 2, Finitude et culpabilité: 1 - L'homme faillible; 2 - La symbolique du mal, Aubier-Montaigne, 1963.

5 Jacques Derrida, La mythologie blanche. La métaphore dans le texte philosophique. In: Marges, Ed. Minuit, 1972, p. 247-324.

6 Infelizmente, o terceiro volume, que recolhe os resultados dos dois primeiros, ainda não foi traduzido.

7 Nesse contexto, preferiria acentuar o lado ativo da palavra récit e traduzir Temps et récit por Tempo e narração em vez de Tempo e narrativa, como o faz, de maneira correta, mas mais fraca, Constança Marcondes Cesar.

8 Uma boa introdução a essa temática encontra-se no precioso livrinho de Benedito Nunes, O tempo na narrativa, Ática, 1988. 
9 Prefiro a tradução enredo à de intriga, em razão das conotações palacianas dessa última palavra. Enredo também remete a rédeas e a outros fios tecidos pelo texto!

10 Ricoeur não exclui, é evidente, as outras artes, em particular essa arte do tempo que é a música; mas suas análises restringem-se à linguagem verbal, mais próxima da linguagem conceitual filosófica.

11 Temps et récit III, Le temps raconté, Seuil, 1985.

12 Marcel Proust, Em busca do tempo perdido, v. VII, O Tempo redescoberto, Ed. Globo, 1983 , p. 240, tradução modificada.

13 Olivier Mongin, op. cit., p. 209-210.

14 Walter Benjamin, Gesammelte Schriften II-3, p. 1219, Ed. Suhrkamp, 1977.

15 In: Tempset récit de Paul Ricoeur en débat, publicado por Christian Bouchindhomme \& Rainer Rochlitz, Seuil, 1990, p. 35.

Jeanne Marie Gagnebin é professora do Programa de Pós-Graduação em Filosofia da Pontifícia Universidade Católica de São Paulo (PUC-SP) e do Departamento de Teoria Literária da Unicamp. 